\title{
Analisis Regresi Model Produktivitas Tenaga Kerja Industri Kecil Keripik Singkong Di Desa Kasarangan Kecamatan Labuan Amas Utara Kabupaten Hulu Sungai Tengah
}

\section{(Regression Analysis of Labor Productivity Factors of Cassava Chips Small Industries in Kasarangan Village Labuan Amas Utara District Hulu Sungai Tengah Regency)}

\author{
Miranda Romaully Br. Sitanggang ${ }^{1)}$ \& Syahriati ${ }^{2)}$ \\ Program Studi Agribisnis, Sekolah Tinggi Ilmu Pertanian Amuntai \\ ${ }^{1)}$ miranda.rsd2203@gmail.com \\ ${ }^{2)}$ syahriati@gmail.com
}

\begin{abstract}
ABSTRAK
Tingkat produktivitas merupakan salah satu ukuran yang menentukan keberhasilan suatu perusahaan dalam persaingan di dunia usaha. Unsur-unsur penting yang dapat meningkatkan produktivitas total perusahaan yaitu tenaga kerja, modal, produksi, organisasi dan pemasaran dimana unsur yang paling mampu memberikan keuntungan terbesar adalah tenaga kerja. Penelitian ini bertujuan untuk menganalisis faktor apa saja yang mempengaruhi produktivitas tenaga kerja pada industri kecil keripik singkong yang ada di Desa Kasarangan. Berdasarkan hasil penelitian Industri kecil keripik singkong di Desa Kasarangan merupakan suatu usaha ekonomi yang masih bersifat sederhana dimana manajemen yang dilaksanakan masih bersifat tradisional, belum diikuti oleh perkembangan teknologi yang cukup berarti. Peralatan yang digunakan masih peralatan sederhana dan penggunaan peralatan untuk melakukan proses produksi masih didominasi oleh tenaga manusia, sehingga produktivitas tenaga kerja pada industri kecil keripik singkong masih relatif rendah. Dari hasil perhitungan koefisien determinasi (R2) diperoleh nilai sebesar 50,9\%. Hal ini berarti menunjukkan adanya keragaman produktivitas tenaga kerja yang dapat di jelaskan oleh variabel yang digunakan. Sedangkan sisanya sebesar 49,1\% di jelaskan oleh variabel-variabel lain yang tidak terdapat dalam model. Faktor-faktor yang berpengaruh nyata terhadap produuktivitas tenaga kerja yaitu alokasi waktu dengan nilai t-hitung sebesar 2,423 lebih besar dari t-tabel (2,423>1,696) dengan nilai sig sebesar 0,021 lebih kecil dari alpha (0,021<0,05). Sedangkan faktor umur, pendidikan, jumlah tanggungan, pengalaman kerja, jenis kelamin, dan status pekerjaan (dummy) tidak berpengaruh nyata terhadap produktivitas tenaga kerja.
\end{abstract}

Kata kunci : Industri, rumah tangga, analisis, regresi, determinasi.

\begin{abstract}
Productivity level is one measure that determines the success of a company in competition in the business world. Important elements that can increase the total productivity of the company are labor, capital, production, organization and marketing where the most able element to provide the greatest benefits is labor. This study aims to analyze what factors influence labor productivity in the small industry of cassava chips in Kasarangan Village. Based on the research results, the small industry of cassava chips in Kasarangan Village is a simple economic undertaking where the management carried out is still traditional in nature, not yet followed by significant technological developments. The equipment used is still simple equipment and the use of equipment to carry out the production process is still dominated by human power, so labor productivity in the small industry of cassava chips is still relatively low. From the calculation of the coefficient of determination (R2) obtained a value of 50.9\%. This means that there is a diversity of labor productivity that can be explained by the variables used. While the remaining $49.1 \%$ is explained by other variables not contained in the model. Factors that significantly influence labor productivity are time allocation with a t-count value of 2.423 greater than $t$ table (2.423> 1.696) with a sig value of 0.021 smaller than alpha $(0.021<0.05)$. While the factors of age, education, number of dependents, work experience, gender, and employment status (dummy) did not significantly affect labor productivity.
\end{abstract}

Keywords : Industry, household, analysis, regression, determination. 


\section{PENDAHULUAN}

Pembangunan sektor ekonomi juga memperhatikan subsektor industri kecil dan kerajinan yang mempunyai potensi dan peranan penting. Keberadaannya yang sebagian besar berada di pedesaan tentunya menjadikan industri kecil dan kerajinan ini memberikan sumbangan bagi daerahnya.

Konsep Agribisnis dengan industri pengolahan hasil pertanian (agroindustri) yang ditangani secara utuh, mulai dari proses produksi, mengolah hasil, pemasaran, dan aktivitas lain yang berkaitan dengan kegiatan pertanian (sistem agribisnis) bukan hanya mampu sebagai sumber pertumbuhan baru bagi sektor pertanian, tetapi juga mampu menyerap banyak tenaga kerja dan mampu meningkatkan nilai tambah (Soekartawi, 2001).

Peranan yang cukup penting dan strategi dari industri kecil ini dalam perekonomian sangat erat kaitannya dengan sifat-sifat dasar dari industri kecil itu sendiri yaitu: Pertama, industri kecil pada umumnya bersifat sangat local labour intensive, artinya bahwa industri kecil sangat mengandalkan pada penggunaan tenaga kerja yang berasal dari sekitarnya (tenaga kerja lokal). Kedua, industri kecil sangat intensif dalam pemakaian sumber-sumber alam lokal. Ketiga, industri kecil banyak dijumpai di daerah pedesaan. Keempat, sebagian besar industri kecil sangat erat hubungannya dengan sektor pertanian. Kelima, sebagian besar industri kecil membuat barang-barang konsumsi dan industri untuk memenuhi kebutuhan pasar lokal dengan tingkat harga yang terjangkau terutama bagi kalangan manyarakat yang berpenghasilan menengah ke bawah (Tambunan, 2001).

Kabupaten Hulu Sungai Tengah merupakan salah satu Kabupaten yang ada di provinsi Kalimatan Selatan yang mempunyai prospek pekonomian yang cukup baik karena letaknya yang strategis. Selain sebagai pusat perdagangan di Kabupaten Hulu Sungai Tengah juga banyak berkembang industri-industri kecil, salah satunya indusrti kecil keripik singkong. Komoditas tanaman singkong di pasar Keramat Barabai mengalami kenaikan tinggi karena banyaknya permintaan. Selain harganya murah singkong juga bisa diolah menjadi berbagai macam makanan dan camilan.

Sentra industri keripik singkong di Kabupaten Hulu Sungai Tengah terletak di Desa Kasarangan dan Desa Kadundung Kecamatan Labuan Amas Utara. Sentra industri keripik ini mulai berkembang sejak tahun 2000. Awalnya industri ini hanya di lakukan dengan menggunakan tenaga kerja keluarga saja, namun seiring waktu industri ini semakin berkembang dan hampir seluruh warga masyarakatnya menggeluti usaha ini, karena banyaknya permintaan pasar yang menyukai hasil produksi keripik ini.

Tabel 1. Data Perkembangan Produksi Keripik Singkong di Kecamatan Labuan Amas Utara Kabupaten Hulu Sungai Tengah Tahun 2008-2012

\begin{tabular}{ccccccc}
\hline \multirow{2}{*}{ No } & Desa & \multicolumn{5}{c}{ Kapasitas Produksi Keripik Singkong (Kg) } \\
\cline { 3 - 7 } & & 2008 & 2009 & 2010 & 2011 & 2012 \\
\hline 1 & Kasarangan & 419.000 & 425.000 & 434.000 & 441.000 & 452.000 \\
2 & Kadundung & 273.000 & 293.000 & 298.000 & 304.000 & 310.000 \\
\hline & Total & 692.000 & 718.000 & 732.000 & 745.000 & 762.000 \\
\hline
\end{tabular}

Sumber: Dinas Perindustrian, Pertambangan dan Energi Kabupaten Hulu sungai Tengah, 2012.

Dari tabel diatas dapat dilihat kapasitas produksi keripik singkong dari tahun ke tahun semakin meningkat. Melihat prospek pasar yang cukup menjanjikan industri ini bagus untuk dikembangkan. 
Tabel 2. Data Para Pelaku Industri Keripik Singkong Di Desa Kasarangan Tahun 2012.

\begin{tabular}{|c|c|c|c|c|}
\hline \multirow[t]{2}{*}{ No } & \multirow[t]{2}{*}{ Nama } & Tenaga & Produksi & Nilai Produksi \\
\hline & & Kerja & (Kg/Tahun) & (Rp/Tahun) \\
\hline 1 & Burhanudin & 6 & 36.000 & 900.000 .000 \\
\hline 2 & Rahimah & 3 & 25.000 & 650.000 .000 \\
\hline 3 & Dayah & 3 & 27.000 & 675.000 .000 \\
\hline 4 & Bahrani & 4 & 28.000 & 700.000 .000 \\
\hline 5 & Isna & 3 & 26.000 & 675.000 .000 \\
\hline 6 & Khairun & 4 & 29.000 & 700.000 .000 \\
\hline 7 & Salasiah & 8 & 30.000 & 900.000 .000 \\
\hline 8 & Yogi & 3 & 26.000 & 625.000 .000 \\
\hline 9 & Rahimah & 4 & 27.000 & 675.000 .000 \\
\hline 10 & H. Arjuna & 4 & 32.000 & 725.000 .000 \\
\hline 11 & Halimatus & 4 & 29.000 & 700.000 .000 \\
\hline 12 & Ilin & 3 & 27.000 & 675.000 .000 \\
\hline 13 & Kamah & 4 & 26.000 & 700.000 .000 \\
\hline 14 & Ina & 4 & 29.000 & 725.000 .000 \\
\hline 15 & Siti Arjunah & 3 & 28.000 & 625.000 .000 \\
\hline 16 & Nurlam & 3 & 27.000 & 650.000 .000 \\
\hline & Total & 63 & 452.000 & 11.300 .000 .000 \\
\hline
\end{tabular}

Sumber: Dinas Perindustrian, Pertambangan dan Energi Kabupaten Hulu Sungai Tengah, 2012.

Berdasarkan data industri kecil keripik singkong yang ada di dinas perindustrian tercatat ada 35 pengrajin keripik singkong dengan total tenaga kerjanya 123 orang. Sebanyaka 16 dari 35 pengrajin keripik ini berada di Desa Kasarangan dengan jumlah tenaga kerjanya sebanyak 63 orang.

Industri kecil keripik singkong di Desa Kasarangan mempunyai nilai produksi yang cukup baik. Produksi keripik singkong dalam satu tahun mencapai $452.000 \mathrm{~kg}$ dengan harga Rp. 25.000, /kg sehingga nilai produksinya mencapai Rp.11.300.000.000,/tahun (Tabel 2). Hasil produksi ini biasanya langsung dijual ke pasar-pasar oleh pengusaha. Biasanya keripik tersebut langsung habis terjual dalam satu kali produksi.

Namun dalam pembuatan keripik ini para pengusaha masih banyak menggunakan alat-alat tradisional dan tenaga manual, karena rata-rata masyarakat disana memiliki tingkat pendidikan yang rendah dan keterampilan rendah serta kurang terlatih sehingga produktivitas tenaga kerja dalam menghasilkan produksi yang dihasilkan kurang maksimal.
Penelitian ini bertujuan untuk menganalisa faktor-faktor yang mempengaruhi produktivitas tenaga kerja pada industri kecil keripik singkong di Desa Kasarangan Kecamatan Labuan Amas Utara Kabupaten Hulu Sungai Tengah.

\section{METODE PENELITIAN}

Penelitian dilakukan di Desa Kasarangan Kecamatan Labuan Amas Utara Kabupaten Hulu Sungai Tengah karena Desa Kasarangan merupakan sentra industri kecil keripik singkong yang ada di Kabupaten Hulu Sungai Tengah. Pengambilan data dilapangan dilakukakan selama bulan Mei-Agustus 2013.

Data yang dikumpulkan dan digunakan dalam penelitian ini adalah data primer dan sekunder. Data primer diperoleh wawancara dengan tenaga kerja industri kecil keripik singkong di Desa Kasarangan. Sedangkan data sekunder sebagai penunjang dan pelengkap diperoleh dari Kantor Dinas Perindustrian, Perdagangan dan Badan Pusat Statistik di Kabupaten Hulu Sungai Tengah serta buku-buku dan literatur yang berhubungan dengan penelitian ini. 
Data dikumpulkan dari wawancara dengan responden. Responden diambil dari populasi seluruh tenaga kerja yang bekerja indutri keripik singkong di desa Kasarangan sebanyak 63 orang. responden hanya diambil sebagian dari populasi dengan pembatasan responden adalah tenaga kerja yang pada saat wawancara berada (bekerja) pada industri kecil yang menjadi diteliti di Desa Kasarangan, tenaga kerja yang di wawancarai bukan merupakan tenaga kerja keluarga dan tenaga kerja tersebut telah bekerja di industri keripik singkong di Desa Kesarangan tersebut lebih dari satu tahun. Sehingga data yang dikumpulkan hanya berasal dari 39 tenaga kerja sesuai kriteria tersebut.

Analisis data untuk mengetahui faktor-faktor apa saja yang mempengaruhi produktivitas tenaga kerja yaitu dengan menggunakan analisis regresi linear berganda. Faktor-faktor yang mempengaruhi produktivitas tenaga kerja pada industri keripik ini dibatasi pada beberapa variabel yaitu jenis kelamin, umur, tingkat pendidikan, pengalaman kerja, jumlah tanggungan, alokasi waktu dan status pekerjaan maka dapat dituliskan. Model produktivitas secara ekonometrika (Rahim dan Hastuti, 2007) dapat dituliskan dalam bentuk persamaan linear berganda yaitu :

$\mathrm{Y}=\mathrm{a}+\mathrm{b}_{1} \mathrm{X}_{1}+\mathrm{b}_{2} \mathrm{X}_{2}+\mathrm{b}_{3} \mathrm{X}_{3}+\mathrm{b}_{4} \mathrm{X}_{4}+\mathrm{b}_{5} \mathrm{X}_{5}+. .+\mathrm{b}_{\mathrm{n}} \mathrm{X}_{\mathrm{n}}$ $+\mathcal{E}$

Dimana

$\mathrm{Y}=$ Produktivitas tanaga kerja

$\mathrm{a}=$ konstanta

$\mathrm{b} 1=$ parameter variabel bebas

$\mathrm{X} 1$ = Umur (tahun)

$\mathrm{X} 2=$ Tingkat Pendidikan (tahun)

X3 = Jumlah Tanggungan (orang)

$\mathrm{X} 4=$ Pengalaman kerja (tahun)

X5 = Alokasi Waktu (jam)

$\mathrm{X} 6=$ Jenis kelamin

X7 = Dummy/status Pekerjaan

\section{HASIL DAN PEMBAHASAN}

\section{Tingkat Produktivitas}

Tingkat produktivitas kerja di ukur berdasarkan hasil olahan produksi yang di hasilkan. Jumlah produksi yang diperoleh adalah dari data hasil produksi para tenaga kerja pada setiap bagian dalam pengolahan. Pekerja yang mempunyai produktivitas tinggi adalah pekerja yang bisa mengolah hasil produksi paling banyak. Data produktivitas tenaga kerja pada industri kecil keripik singkong di Desa Kasarangan dapat dilihat pada tabel berikut:

Tabel 3. Data Produktivitas Tenaga Kerja Pada Industri Kecil Keripik Singkong di Desa Kasarangan.

\begin{tabular}{ccc}
\hline Produktivitas $(\mathrm{Kg})$ & Jumlah (orang) & Persentase $(\%)$ \\
\hline 50 & 1 & 2,56 \\
$51-100$ & 9 & 23,08 \\
$101-200$ & 21 & 53,85 \\
$201-300$ & 8 & 20,51 \\
$>301$ & 0 & 0,00 \\
\hline Jumlah & 39 & 100 \\
\hline
\end{tabular}

Dilihat dari tabel di atas jumlah responden yang mempunyai produktivitas paling rendah yaitu $50 \mathrm{~kg}$ sebanyak 1 orang $(2,56 \%)$, responden yang mempunyai produktivitas $51-100 \mathrm{~kg}$ sebanyak 9 orang $(23,08 \%)$, responden yang mempunyai produktivitas antara $101-200 \mathrm{~kg}$ adalah yang paling banyak yaitu 21 orang $(53,85 \%)$, sedangkan responden yang mempunyai produktivitas paling tinggi yaitu $201-300 \mathrm{~kg}$ sebanyak 8 orang $(20,51 \%)$.

\section{Hasil Analisis Regresi}

Model analisis pendugaan fungsi faktor-faktor yang mempengaruhi produktivitas tenaga kerja pada industri kecil keripik singkong menggunakan model regresi linier berganda. Produktivitas dijadikan sebagai variabel terikat (dependent 
variabel). Variabel lain yang dimasukkan dalam variabel bebas (independent variabel), seperti: Umur (X1), Pendidikan (X2), Jumlah Tanggungan Keluarga (X3), Pengalaman Kerja (X4), Alokasi Waktu (X5), Dummy Jenis Kelamin (X6), Dummy status pekerjaan $(\mathrm{X} 7)$.

Hasil pendugaan model penentu produktfitas tenaga kerja pada industri

Tabel 4. Hasil Analisis Regresi Faktor Yang Mempengaruhi Produktivitas Pekerja Industri Kecil Keripik Singkong di Desa Kasarangan.

\begin{tabular}{clccccc}
\hline No. & \multicolumn{1}{c}{ Parameter } & Notasi & $\begin{array}{c}\text { Koefisien } \\
\text { Parameter }\end{array}$ & $\mathrm{t}$ & Sig & VIF \\
\hline 1 & Costanta & $\alpha$ & $-86,249$ & $-1,048$ & 0,303 & \\
2 & Umur & $\mathrm{X} 1$ & 1,094 & 0,677 & 0,504 & 3,291 \\
3 & Pendidikan & $\mathrm{X} 2$ & 5,916 & 1,425 & 0,164 & 1,595 \\
4 & Jumlah & $\mathrm{X} 3$ & 7,59 & 0,686 & 0,498 & 2,812 \\
5 & Tanggungan & $\mathrm{X} 4$ & 8,384 & 1,337 & 0,191 & 3,767 \\
6 & Pengalamn Kerja & $\mathrm{X} 5$ & 21,596 & 2,423 & $0,021^{*}$ & 2,554 \\
7 & Alokasi Waktu & $\mathrm{X} 6$ & 3,001 & 0,18 & 0,858 & 1,348 \\
8 & Jenis Kelamin & $\mathrm{X} 7$ & $-31,787$ & $-1,221$ & 0,231 & 2,177 \\
& Dummy & & & & & \\
\hline R & $\quad: 59,9$ & & & & & \\
$\mathrm{R}-$ adjust $\quad: 39,8$ & & & & & & \\
F-hitung $\quad: 4,594$ & & & & & &
\end{tabular}

Ket : *** berpengaruh nyata pada $\alpha=0,05$

** berpengaruh nyata pada $\alpha=0.20$

* berpengaruh nyata pada $\alpha=0.25$

Dari hasil pengujian pendugaan dengan analisis regresi liniear berganda dilihat dari tabel diatas, dimana diketahui nilai koefisien determinasi atau $\mathrm{R}^{2}$ sebesar $50,9 \%$. Hal ini berarti menunjukan bahwa keragaman produktivitas pekerja dapat dijelaskan oleh variabel yang digunakan, sedangakan sisanya sebesar $49,1 \%$ dijelaskan oleh variabel lain yang tidak dimasukan ke dalam model.

Hasil uji F-hitung dari dari model fungsi diatas sebesara 4,594 dengan nilai signifikan 0,001. Hasil tersebut lebih besar dari nilai F-tabel yaitu 2,323. Dengan demikian dapat dinyatakan bahwa semua variabel bebas (X) secara simultan berpengaruh nyata terhadap produktivitas pekerja.

\section{Faktor Penentu Produktivitas Tenaga Kerja}

keripik singkong di Desa Kasarangan adalah:

$\mathrm{Y}=86,249+1,094 \mathrm{X} 1+5,916 \mathrm{X} 2+7,590 \mathrm{X} 3+8$, 384X4+21,569X5+3,001X6- 31,787X7

Hasil perhitungan parameter dari masing-masing variabel yang diduga berpengaruh terhadap produktivitas pekerja dapat dilihat pada tabel di bawah ini:

$$
\text { (1) }
$$


Pendidikan menunjukkan tingkat pendidikan formal yang pernah di tempuh seseorang. Pendidikan adalah program yang disediakan sebagai persiapan sebelum seseorang memasuki pekerjaan. Dari hasil pengujian koefisien regresi variabel pendidikan dengan t-hitung sebesar 1,425 dengan nilai sig 0,164 lebih kecil dari pada alpha $20 \%(0,164<0,2)$. Pendidikan berpengaruh terhadap produktifitas mengingat $72,05 \%$ dari responden berpendidikan SLTP ke atas. Jadi jika tenaga kerja memiliki tingkat pendidikan yang lebih tinggi akan menambah produktifitas 5,916 satuan.

\section{Tanggungan Keluarga (X3)}

Jumlah tanggungan keluarga meningkatkan produktivitas pekerja dengan bertambahnya jumlah tanggungan seorang pekerja, namun tidak berpengaruh nyata. Hasil pengujian koefisien regresi variabel tanggungan keluarga dengan t-hitung sebesar 0,686 dengan nilai sig 0,498 lebih besar dari pada alpha $25 \%(0,498>0,25)$. Hal ini menunjukan bahwa variabel tanggungan keluarga secara parsial tidak berpengaruh nyata terhadap produktivitas pekerja.

Hasil ini sama dengan penelitian Akmal (2006) bahwa tanggungan keluarga tidak berpengaruh nyata terhadap produktivitas tenaga kerja karena hanya nyata pada taraf $20 \%$ dengan nilai alpha 0,80. Hal ini di duga karena walaupun seorang pekerja memiliki jumlah tanggungan yang banyak, bukan berarti pekerja tersebut menanggung sepenuhnya biaya hidup tanggungannya.

\section{Pengalaman Kerja (X4)}

Pengalaman dalam pekerjaan pada umumnya untuk meningkatkan kemampuan kerja seseorang. Hasil pengujian koefisien regresi variabel pengalaman kerja dengan thitung sebesar 1,337 dengan nilai sig 0,191 lebih kecil dari pada alpha $20 \%(0,191<$ $0,2)$. Hal ini menunjukan bahwa variabel pengalaman kerja secara parsial berpengaruh terhadap produktivitas pekerja.

Hasil ini tidak sejalan dengan hasil penelitian Akmal (2006) pengalaman kerja pada industri kecil kerupuk Sinjai tidak memberikan pangaruh yang nyata terhadap produktivitas pekerja, karena pekerja yang mempunyai pengalaman yang tinggi mempunyai keterampilan dalam membuat kerupuk lebih baik, akan tetapi rata-rata pekerja yang berpengalaman tinggi telah berusia tua sehingga kemampuan dalam bekerja mulai menurun. Sedangkan pada industri kecil keripik singkong di Desa Kasarangan pengalaman menentukan produktivitas tenaga kerja karena sebanyak $51,28 \%$ tenaga kerja sudah bekerja selama 4 tahun lebih sehingga memiliki keterampilan yang cukup dari pengalaman kerjanya. Sehingga setiap bertambah satu tahun pengalaman kerja akan meningkatkan produktifitas sebesar 8,384 satuan.

\section{Alokasi Waktu (X5)}

Dari hasil pengujian koefisien regresi untuk variabel alokasi waktu dengan thitung sebesar 2,423 lebih besar dari t-tabel $(2,423>1,696)$ dan nilai sig 0,021 lebih kecil dari pada alpha $5 \%(0,021<0,05)$. Hal ini menunjukan bahwa variabel alokasi waktu secara parsial berpengaruh nyata terhadap produktivitas pekerja pada industri kecil keripik singkong. Alokasi waktu pada industri kecil keripik singkong berbeda tergantung dengan jenis kegiatan masingmasing pekerja.

Hasil ini sejalan dengan pengujian Akmal (2006) alokasi waktu memberikan pengaruh nyata terhadap produktivitas pekerja dengan taraf kepercayaan 99\% $(\alpha=$ 0,01 ). Jadi alokasi waktu pada industri kecil keripik singkong yang ada di Desa Kasarangan berpengaruh nyata terhadap produktivitas tenaga kerja dimana koefisiennya bernilai positif, artinya apabila terjadi peningkatan jam kerja sebanyak 1 jam maka diduga akan meningkatkan produktifitas sebesar $21,569 \mathrm{~kg} /$ jam keripik singkong.

\section{Dummy Jenis Kelamin (X6)}

Tenaga kerja pada dasarnya tidak dapat dibedakan berdasarkan pada jenis kelamin. Dari hasil pengujian koefisien regresi variabel jenis kelamin dengan thitung sebesar 0,180 dengan nilai sig 0,858 
lebih besar dari pada alpha 25\% (0,858 > 0,25). Hal ini menunjukan bahwa variabel jenis kelamin secara parsial tidak berpengaruh nyata terhadap produktivitas pekerja pada industri kecil keripik singkong.

Jenis kelamin pada industri kecil keripik singkong yang ada di Desa Kasarangan tidak berpengaruh nyata terhadap produktivitas tenaga kerja hal ini disebabkan karena mereka mempunyai bidang pekerjaan yang berbeda-beda pada pengolahan keripik singkong.

\section{Dummy Status Pekerjaan (X7)}

Dummy status pekerjaan adalah seseorang yang bekerja pada industri kecil keripik singkong secara penuh (pekerjaan utama) atau paruh waktu (pekerjaan sampingan). Dari hasil pengujian koefisien regresi variabel dummy dengan t-hitung sebesar -1,221 dengan nilai sig 0,231 lebih kecil dari pada alpha $25 \%(0,231<0,25)$. Hal ini menunjukan bahwa variabel dummy secara parsial berpengaruh nyata terhadap produktivitas pekerja pada industri kecil keripik singkong. Besaran koefisiennya bertanda negatif jadi tenaga kerja yang bekerja paruh waktu jika menjadi penuh waktu akan mengurangi produktifitasnya sebesar 31,787 satuan.

\section{KESIMPULAN}

Industri kecil keripik singkong di Desa Kasarangan merupakan suatu usaha ekonomi yang masih bersifat sederhana dimana manajemen yang dilaksakan masih bersifat tradisional. Peralatan yang digunakan masih peralatan sederhana dan penggunaan peralatan untuk melakukan proses produksi masih didominasi oleh tenaga manusia, sehingga produktivitas tenaga kerja pada industri kecil keripik singkong masih relatif rendah. Dari hasil perhitungan koefisien determinasi $\left(\mathrm{R}^{2}\right)$ diperoleh nilai sebesar 50,9\%. Hal ini berarti menunjukkan adanya keragaman produktivitas tenaga kerja yang dapat di jelaskan oleh variabel yang digunakan. Sedangkan sisanya sebesar $49,1 \%$ di jelaskan oleh variabel-variabel lain yang tidak terdapat dalam model.

Faktor-faktor penentu terhadap produktivitas tenaga kerja yaitu pendidikan, pengalaman kerja, alokasi waktu dan dummy status pekerjaan Sedangkan faktor umur, jumlah tanggungan, dan jenis kelamin (dummy) tidak cukup menentukan keragaan produktivitas tenaga kerja secara parsial.

\section{DAFTAR PUSTAKA}

Akmal, Yori. 2006. Analisis faktor-faktor yang mempengaruhi produktivitas tenaga kerja industri kecil Kerupuk Sanjai di Kota Bukittinggi. Skripsi. Institut Pertanian Bogor. Bogor.

Rahim dan Hastuti. 2007. Ekonometrika Pertanian (Pengantar, Teori, dan Kasus). Penebar Swadaya. Depok.

Soekartawi. 2001. Agribisnis Teori dan Aplikasi. PT. Radja Grafindo Persada. Jakarta.

Tambunan, T. T. H. 2001. Industrialisasi Di Negara Sedang Berkembang Kasus Indonesia. Ghalia Indonesia. Jakarta. 